\title{
Dormancy as a survival strategy of the fish pathogen Streptococcus parauberis in the marine environment
}

\author{
M. Currás, B. Magariños, A. E. Toranzo, J. L. Romalde* \\ Departamento de Microbiología y Parasitología, Facultad de Biología, Universidad de Santiago de Compostela, \\ 15782 Santiago de Compostela, Spain
}

\begin{abstract}
The fate of Streptococcus parauberis in seawater and sediment microcosms at different temperatures $\left(6\right.$ and $22^{\circ} \mathrm{C}$ ) was investigated by comparing the survival dynamics of 2 strains of this bacterial species, isolated respectively from diseased turbot and cattle. The turbot and the bovine isolate showed similar survival kinetics, remaining culturable for approximately 1 mo in water and 6 mo in sediment. A slight influence of temperature on the stability of the cells was observed, in that the number of culturable cells was about $1 \log _{10}$ unit higher at 6 than at $22^{\circ} \mathrm{C}$. During the starvation period, the metabolic activity of the cells, after suffering a strong reduction during the first $12 \mathrm{~d}$, stabilized at levels ranging from 20 to $40 \%$ of the initial values. However, in all the microcosms, the acridine orange (AO) and 4',6-diamidino-2-phenilindole (DAPI) counts remained at about $10^{5} \mathrm{cells} \mathrm{ml}^{-1}$ throughout the experimental period, even when cells became undetectable by standard plate count methods. The addition of fresh medium to microcosms containing nonculturable cells induced the return to culturability of $S$. parauberis strains. On the basis of these results, it seems that $S$. parauberis has the ability to enter into a viable but nonculturable (VBNC) state. Dormant cells of the turbot isolate maintained their infectivity and pathogenic potential for fish.
\end{abstract}

KEY WORDS: Streptococcus parauberis · Fish pathogen · Survival · Viable but nonculturable state

\section{INTRODUCTION}

Streptococcal diseases have been reported worldwide in wild and farmed populations of diverse freshwater and marine fish (Austin \& Austin 1993, Kusuda \& Salati 1993). In 1993, there was an important epizootic outbreak of streptococcosis in turbot Scophthalmus maximus cultured in Galicia (NW Spain) that was initially thought to be caused by an Enterococcus specieslike bacterium (Toranzo et al. 1994). From 1993 to 1996, the disease was the main limiting factor of the turbot culture in Spain (Toranzo et al. 1995, Romalde et al. 1996). Characterization studies, including phenotypic, serological and genetical aspects, have been car-

*Corresponding author. E-mail: mpromald@usc.es ried out showing a great homogeneity of the isolates regardless of their farm and year of isolation (Toranzo et al. 1994, 1995, Romalde et al. 1999a). Further studies of the 16S rRNA genes demonstrated that these fish isolates belonged to the species Streptococcus parauberis, a recognized pathogen of mammals (Domenech et al. 1996). Preventive measures, based on the employment of a bacterin developed in our laboratory (Romalde et al. 1999b), allow the control of the disease. However, streptococcosis seems to be endemic in some turbot farms, posing a putative danger of new outbreaks. Although some studies have been performed regarding the possible routes of infection in cultured turbot (Toranzo et al. 1994, Romalde et al. 1996), little is known about the behavior of the strains in the aquatic environment or the possible role of water or sediments as reservoirs of the disease. 
Many bacteria, including a number of fish pathogens, are able to survive for a long time under conditions of starvation in the aquatic environment (Oliver et al. 1991, Magariños et al. 1994, 1997, Romalde et al. 1994). During this time, they may enter a 'dormant' or viable but nonculturable (VBNC) state, in which neither plating onto solid media nor inoculation into liquid media reveals the presence of viable cells (Roszak \& Colwell 1987, Oliver et al. 1991, 1995). It has been shown that some environmental parameters, like temperature, $\mathrm{pH}$ or aeration, can induce bacteria to enter into the VBNC state (Oliver et al. 1991, 1995, Colwell 2000). Among the cell changes reported for VBNC state are reduction in size, altered surface hydrophobicity, differences in protein and plasmid profiles, and variations in random amplified polymorphic DNA (RAPD) patterns (Nyström et al. 1992, Magariños et al. 1994, Warner \& Oliver 1998).

Although VBNC bacterial cells do not form colonies when plated on culture medium, their direct microscopic counts are constant and they maintain viability. This means that it is necessary to work with other methods to test the presence of these bacteria in aquatic environments (Morgan \& Winstanley 1996, Colwell 2000). Epifluorescence microscopy, using fluorescent labeled antibodies, combined use of propidium iodide and molecular probes, and amplification of bacterial mRNA by reverse transcription polymerase chain reaction (RT-PCR) procedures (Warner \& Oliver 1998, Williams et al. 1998, Lleó et al. 2000) are some of the methods recently employed to detect VBNC cells in the environment. The ability of VBNC bacteria to resume their growth capacity when returning to optimal conditions seems to be variable among species (Roszak \& Colwell 1987), although some recent studies indicate that there is a threshold beyond which recuperation is no longer possible (Lleó et al. 1998, Colwell 2000). The VBNC state is now considered a survival strategy common to numerous bacterial species (Colwell \& Grimes 2000).

Another crucial point regarding the VBNC state, especially important in the case of bacterial fish pathogens, is the maintenance of their pathogenic potential during dormancy. This fact has been demonstrated for some Gram-negative fish pathogens such as Photobacterium damselae subsp. piscicida and Yersinia ruckeri (Magariños et al. 1994, Romalde et al. 1994). Therefore, the VBNC state constitutes a potential risk for fish farms, since even an environment that appears free of pathogens by means of direct plate counts can harbor a high number of infective bacteria in water and sediment in a nonculturable phase, which may result in new outbreaks.

In the present study, the behavior of cells of Streptococcus parauberis in the marine environment under starvation conditions was evaluated. Their ability to enter and recuperate from a VBNC state, and the maintenance of virulence during dormancy were examined.

\section{MATERIALS AND METHODS}

Bacterial strains and preparation of the microcosms. For this study, the isolate RA-99.1 of Streptococcus parauberis, recovered in 1993 from diseased turbot in our laboratory, was chosen as the representative strain since, as previously described (Toranzo et al. 1994, 1995), all the fish isolates show a high phenotypic and genetic homogeneity. Reference strain $S$. parauberis NCDO 2020, isolated from cattle in 1995, was included in all the experiments for comparative purposes. The phenotypic and serological characteristics of the isolates have been described elsewhere (Toranzo et al. 1994, 1995).

The survival assays were conducted in seawater (salinity 27.5\%) and sediment (taken from Ría de Pontevedra, Galicia, NW Spain), which were transported in cold storage containers and kept at $4^{\circ} \mathrm{C}$ until use (within $48 \mathrm{~h}$ ). Water was filtered through $0.2 \mu \mathrm{m}$ poresize membranes (Millipore), and sediment was autoclaved at $120^{\circ} \mathrm{C}$ for $30 \mathrm{~min}$. The experimental assays were conducted in Erlenmeyer flasks. Water microcosms contained $200 \mathrm{ml}$ of water, and sediment microcosms contained $160 \mathrm{~g}$ of sediment and $40 \mathrm{ml}$ of water. Flasks were incubated in the dark on a rotary shaker at 2 different temperatures, 6 and $22^{\circ} \mathrm{C}$, which correspond to the minimal and maximal temperatures scored in the NW Spain coastal waters. Therefore, a total of 8 microcosms were prepared in duplicate to be included in the survival study.

To obtain the bacterial inocula, the strains were grown on tryptone soy agar (TSA; Difco Laboratories) supplemented with $1 \%(\mathrm{w} / \mathrm{v}) \mathrm{NaCl}(\mathrm{TSA}-1)$ at $22^{\circ} \mathrm{C}$ for $48 \mathrm{~h}$. Cultures of each strain were resuspended in phosphate buffered saline ( $\mathrm{PBS}_{\text {; }} \mathrm{pH}$ 7.4) to achieve an initial bacterial concentration in the microcosms of approximately $10^{5}$ cells $\mathrm{ml}^{-1}$.

Direct plate counts. To determine the culturability of cells in each microcosm, samples of $0.5 \mathrm{ml}$ were taken every $2 \mathrm{~d}$ from water microcosms and every $4 \mathrm{~d}$ from sediment microcosms. Samples were serially diluted in PBS, plated on TSA-1 plates and incubated for $2 \mathrm{~d}$ at $22^{\circ} \mathrm{C}$. Since many copiotropic microorganisms are sensitive to rich media after undergoing nutrient starvation, all samples were inoculated in parallel onto 1/10 diluted TSA-1. Once the direct plate counts were negative, samples of $1 \mathrm{ml}$ were taken directly from the microcosms at later timepoints and were seeded onto TSA-1 and diluted TSA-1. If culturable bacteria could 
not be recovered under these conditions, samples of $100 \mathrm{ml}$ (water) or $20 \mathrm{ml}$ (sediment) were then filtered through a $0.22 \mu \mathrm{m}$ filter (Alvet) and filters were incubated onto TSA-1 plates for $2 \mathrm{~d}$ at $22^{\circ} \mathrm{C}$.

Epifluorescence microscopy and metabolic activity. The number of total bacteria was evaluated by epifluorescence microscopy employing 4', 6-diamidino-2-phenilindole (DAPI; Sigma) and acridine orange (AO; Sigma)( Porter \& Fieg 1980, Hoff 1989). Samples, taken every $10 \mathrm{~d}$, were fixed with formalin, diluted and stained with AO (final concentration $1 \mu \mathrm{g} \mathrm{ml}^{-1}$ ) or DAPI (final concentration $0.1 \mu \mathrm{g} \mathrm{ml}^{-1}$ ). All solutions were sterilized by filtration. After 7 min incubation, samples were filtered onto $0.22 \mu \mathrm{m}$ black Nuclepore filters (GTBP filtertype; Nuclepore). The prepared filters were observed for total cell counts. At least 10 fields from each filter were counted.

The metabolic activity of the cells in the different microcosms was determined by measuring the absorbance at $600 \mathrm{~mm}\left(A_{600}\right)$ with 3-(4,5-dimethylthiazol-2yl)-2,5-diphenyltetrazolium bromide (MTT; Sigma Chemical) (Magariños et al. 1994). This method is based on the reduction of the compound MTT by the bacterial dehydrogenases in direct proportion to the number of viable cells. The results were expressed as the percentage of the remaining respiratory activity, taking as $100 \%$ the value at zero time.

Analysis of cellular changes. The possible morphological, size and serological changes of the strains after entering into the VBNC state were analyzed. Dormant cells were recovered by centrifugation of $10 \mathrm{ml}$ aliquots of each microcosm, 3, 9, 16 and $20 \mathrm{wk}$ after reaching the VBNC phase. The pellets were washed several times with sterile seawater, resuspended in $100 \mu \mathrm{l}$ of saline solution $(\mathrm{SS} ; 0.85 \% \mathrm{NaCl}$ ) and employed for the different assays. Morphological and size variations between culturable and nonculturable cells were evaluated microscopically using micrometric measures. Serological changes of the dormant Streptococcus parauberis isolates were analyzed by a slide agglutination and microagglutination tests using whole cells and their respective antisera raised in New Zealand rabbits (Toranzo et al. 1995).

Virulence for fish. Sixteen weeks after entering the VBNC phase, dormant cells of both strains, the turbot isolate RA-99.1 and the cattle isolate NCDO 2020, were obtained from the water microcosms maintained at $6^{\circ} \mathrm{C}$ by centrifugation of $40 \mathrm{ml}$ aliquots at $10000 \times \mathrm{g}$ for $20 \mathrm{~min}$. The pellets were washed with $1 \mathrm{ml} \mathrm{SS}$, centrifuged at $10000 \times g$ for $15 \mathrm{~min}$ and resuspended in $1 \mathrm{ml}$ sterile SS. Bacterial cell concentration was calculated on the basis of the DAPI counts and adjusted to the appropriate concentration, and then $0.1 \mathrm{ml}$ was injected intraperitoneally into groups of 10 turbot $(5 \mathrm{~g}$ average weight), which were maintained at 18 to $20^{\circ} \mathrm{C}$ with aeration (Magariños et al. 1994). In parallel, the original strains, which were maintained frozen in tryptone soy broth supplemented with $1 \% \mathrm{NaCl}$ (TSB-1) supplemented with $15 \%$ glycerol, were inoculated as positive control. Culturable and nonculturable cells were inoculated at a concentration of $3 \times 10^{4}$ cells fish $^{-1}$, which is slightly higher than the dose at which it kills $50 \%$ of the population $\left(\mathrm{LD}_{50} ; 5 \times 10^{3} \mathrm{cells} \mathrm{fish}^{-1}\right.$ ) (Romalde et al. 1996). Formalin-killed cells from culturable strain RA-99.1 and SS were used as a negative control. The dead fish were examined bacteriologically to reisolate the inoculated strains from the kidney by streaking samples directly onto TSA-1 plates.

Resuscitation conditions. In order to evaluate the reactivation ability of the Streptococcus parauberis strains at the end of the experimental period (Day 180), TSB-1 (Difco) was added to each water microcosm in a proportion 1:10 (v/v). Flasks were incubated at 6 and $22^{\circ} \mathrm{C}$ as described above. After 8, 24 and $48 \mathrm{~h}$ samples were withdrawn, spread onto TSA-1 plates and incubated at $22^{\circ} \mathrm{C}$ to confirm the absence or presence of bacteria.

To determine the effects of different inhibitors on Streptococcus parauberis cell resuscitation, a protein synthesis inhibitor (chloramphenicol; Oxoid; final concentration $100 \mu \mathrm{g} \mathrm{ml}^{-1}$ ) and a peptidoglycan synthesis inhibitor (ampicillin; Oxoid; $100 \mathrm{\mu g} \mathrm{ml}^{-1}$ ) were added to the samples 0,8 , and $24 \mathrm{~h}$ after the strains had been resuscitated by the addition of fresh medium (as described above). The effects of these inhibitors were monitored by plate counts. The 2 inhibitors were selected on the basis of the results of a previous study (Toranzo et al. 1994), where culturable cells of both strains proved to be sensitive to the selected chemotherapeutic agents.

\section{RESULTS}

\section{Survival in the microcosms and evidence of dormancy}

The results obtained in the bacterial counts for the different microcosms reflected similar survival dynamics for the 2 strains regardless of their origin, being persistent for approximately 1 mo in water and 6 mo in sediment (Figs. 1 \& 2). A gradual decrease in bacterial numbers to undetectable levels was observed for all the water microcosms during the first $36 \mathrm{~d}$, with the exception of the turbot isolate RA-99.1 at $22^{\circ} \mathrm{C}$, where the bacterial counts increased (by $1 \log _{10}$ unit) within the first $48 \mathrm{~h}$ (data not shown). The turbot isolate showed a slightly higher persistence in water during the first $36 \mathrm{~d}$ of starvation than the bovine isolate, with differences in the number of colony forming units 

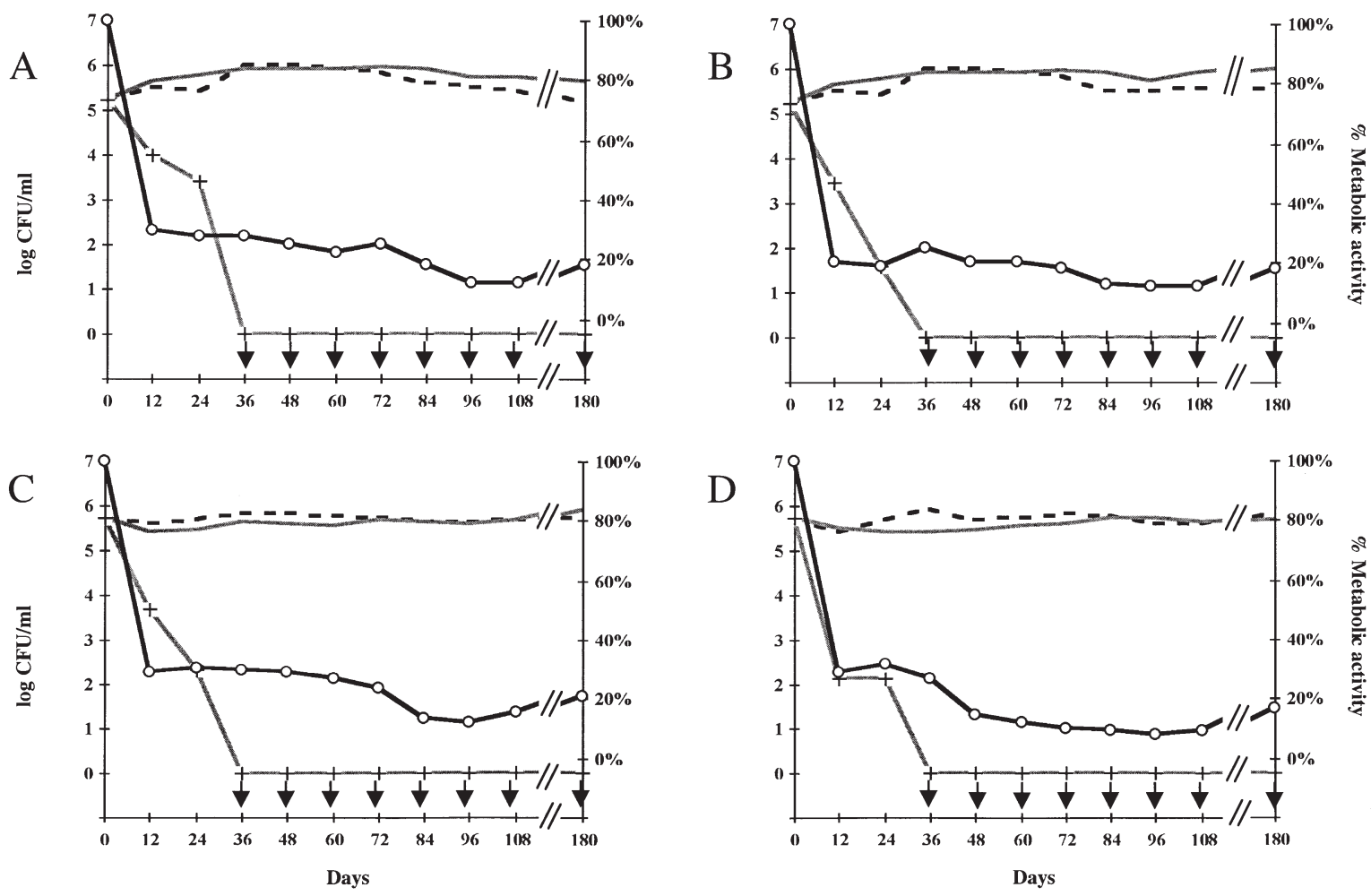

Fig. 1. Survival of Streptococcus parauberis in seawater. (A) Strain RA-99.1 at $6^{\circ} \mathrm{C}_{i}$ (B) strain RA-99.1 at $22^{\circ} \mathrm{C}_{i}(\mathrm{C})$ strain NCDO 2020 at $6^{\circ} \mathrm{C}_{i}$ and (D) strain NCDO 2020 at $22^{\circ} \mathrm{C}$. (-+-) Direct plate counts; (- - ) acridine orange $(\mathrm{AO})$ counts; $(-) 4^{\prime}, 6-$ diamidino-2-phenilindole (DAPI) counts; $(\circ-\infty-\circ)$ metabolic activity. Arrows indicate colony forming unit (CFU) numbers below the detection limit of plating method
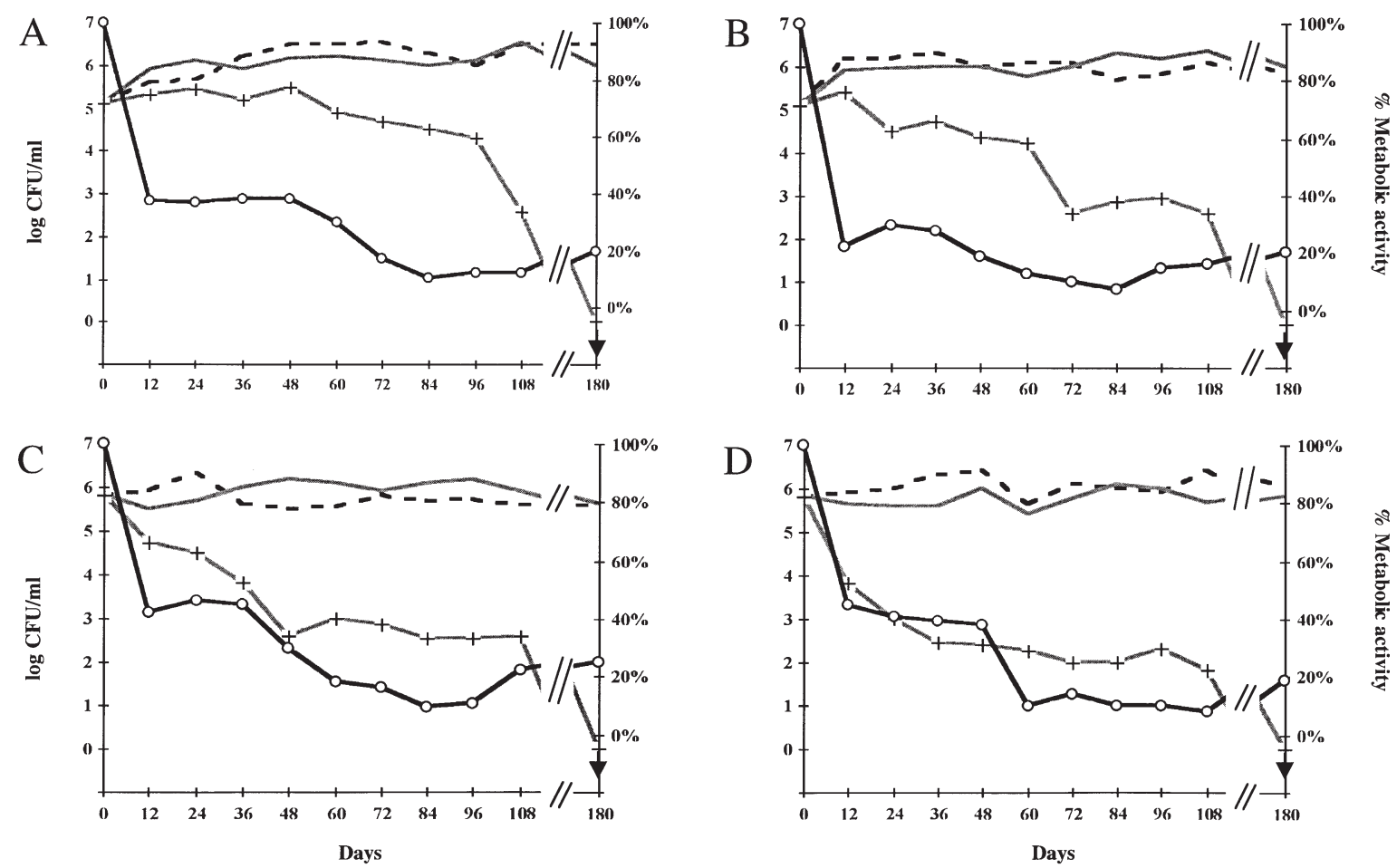

Fig. 2. Survival of Streptococcus parauberis in marine sediment. (A) Strain RA-99.1 at $6^{\circ} \mathrm{C}_{i}(\mathrm{~B})$ strain $\mathrm{RA}-99.1$ at $22^{\circ} \mathrm{C}_{i}(\mathrm{C})$ strain NCDO 2020 at $6^{\circ} \mathrm{C}$; and (D) strain NCDO 2020 at $22^{\circ} \mathrm{C}$. See Fig. 1 for symbol definitions 
(CFU) reaching in some cases $1 \log _{10}$ unit. In the sediment microcosms (Fig. 2), a survival of about $180 \mathrm{~d}$ was obtained for the 2 strains at both temperatures. While strain RA-99.1 almost maintained the initial levels $\left(10^{5}\right.$ CFU ml ${ }^{-1}$ ) for $60 \mathrm{~d}$, bacterial counts of strain NCDO 2020 declined from the beginning of the experiment. Differences in CFU numbers between strains were more evident in sediment than in water, since counts for isolate RA-99.1 were up to $2 \log _{10}$ units higher than for strain NCDO 2020 (Fig. 2). A clear influence of temperature on the survival of the strains was detected, and was more pronounced during the final stages of the experimental period. Thus, CFU were up to $1 \log _{10}$ unit higher in the microcosms of the bovine isolate maintained at $6^{\circ} \mathrm{C}$ than those at $22^{\circ} \mathrm{C}$. In addition, plate counts obtained using a low nutrient medium $(1 / 10$ diluted TSA-1) were similar throughout the experiment to those detected in a rich medium (TSA-1), regardless of the type of microcosm (water or sediment) and the temperature $\left(6\right.$ or $22^{\circ} \mathrm{C}$ ) (data not shown).

Total bacterial numbers were analyzed by epifluorescence microscopy employing 2 different stains, DAPI and AO. In these assays it was found that, after a little increase in the counts in some of the cases, the total counts remained nearly constant during the experimental period, at values of approximately $10^{5}$ to $10^{6}$ bacteria $\mathrm{ml}^{-1}$, even when the number of culturable cells declined to levels below the detection limit (Figs. 1 \& 2). Similar results were achieved for each microcosm with both AO and DAPI staining for both strains.

To demonstrate cell viability, metabolic activity was measured by evaluating respiratory rates. In all cases, respiratory activity was maintained at about $25 \%$ of initial values, even though culturable bacteria were below the limit of detection by the direct plate procedure (Figs. 1 \& 2). Metabolic rates were initially higher in sediment than in water, and at 6 than at $22^{\circ} \mathrm{C}$.

\section{Return to culturability and effect of inhibitors on resuscitation}

Dormant cells of RA-99.1 could be induced to return to a culturable state by addition of fresh medium to the microcosms 20 wk after their entry into the VBNC state. Cells were fully resuscitated $24 \mathrm{~h}$ after the addition of fresh TSB-1 to the microcosms (Fig. 3), reaching $\mathrm{CFU}$ values similar to those of the initial inoculum (approximately $10^{5}$ bacteria $\mathrm{ml}^{-1}$ ) and the same level of metabolic activity as before starvation. Similar results were obtained for the bovine strain NCDO 2020 (data not shown).

When chloramphenicol, a protein synthesis inhibitor, was added immediately after the incorporation of fresh medium, the resuscitation process was completely inhibited, not allowing the recovery of culturable cells within $48 \mathrm{~h}$. The addition of ampicillin, a peptidoglycan synthesis inhibitor, did not affect the resuscitation process, with a kinetic of return to culturability similar to those achieved without addition of inhibitors (Fig. 3). Similar results were obtained when inhibitors were administered $8 \mathrm{~h}$ after the addition of fresh medium. No inhibitory effects were observed when antibiotics were added 24 or $48 \mathrm{~h}$ after the beginning of resuscitation (data not shown).

\section{Virulence assays}

Challenge experiments demonstrated that the nonculturable cells of the Streptococcus parauberis strain RA-99.1 obtained from the water microcosm $16 \mathrm{wk}$ after entering the VBNC state maintained their pathogenic capacity for turbot at levels similar to those of the original culturable strain (positive control). Although in both cases all fish died, a delay in the appearance of the first deaths was observed for fish inoculated with the VBNC cells. Thus, mortalities began $10 \mathrm{~d}$ after inoculation of nonculturable cells instead of $4 \mathrm{~d}$ after injection of culturable $S$. parauberis (Fig. 4). Inoculated strains were always reisolated in pure culture from the internal organs of all dead fish. On the other hand, no specific mortalities were scored in the fish inoculated with the culturable or nonculturable cells of the bovine isolate, for $21 \mathrm{~d}$ after challenge (Fig. 4). No mortalities were recorded in fish injected with killed cells from $S$. parauberis or in fish inoculated with SS.

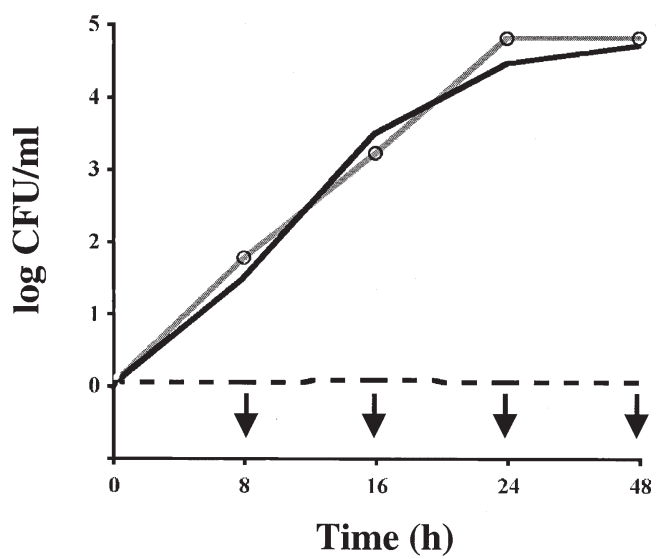

Fig. 3. Effects of the different inhibitors on the resuscitation process of strain RA-99.1 of Streptococcus parauberis. ( $(\bullet-\infty)$ Control cells with no inhibitors added; $(-)$ addition of ampicillin and (- - ) chloramphenicol immediately after the incorporation of fresh medium. Arrows indicate CFU numbers below the detection limit of plating method 


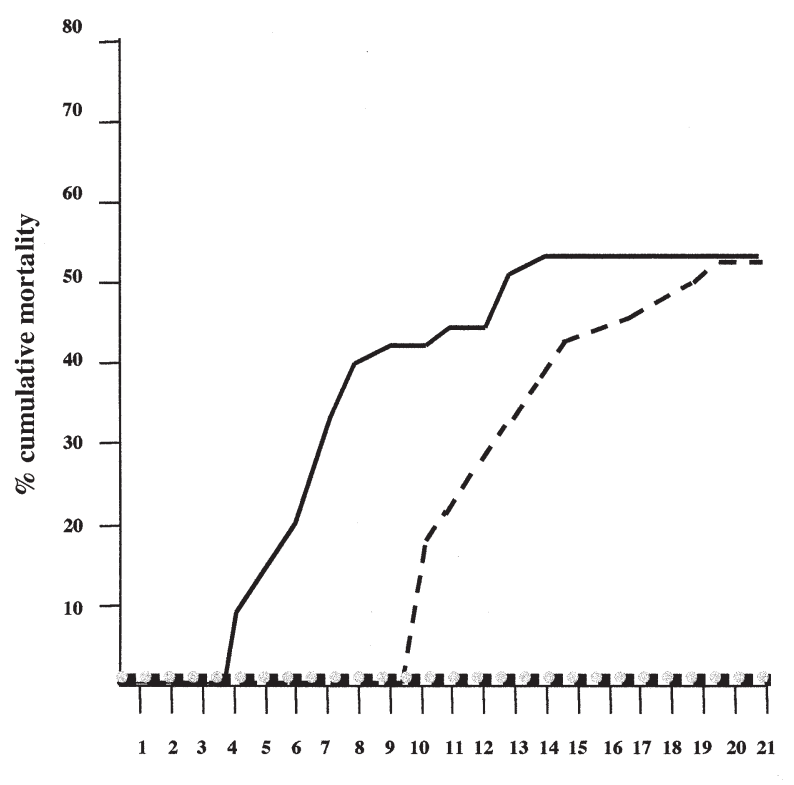

\section{Days post-infection}

Fig. 4. Cumulative specific mortality observed in the different fish groups inoculated with the culturable and nonculturable forms of the turbot and bovine isolates of Streptococcus parauberis. (-) culturable turbot isolate; (- - -) nonculturable turbot isolate; (- - ) culturable bovine isolate; $(\bullet \bullet)$ nonculturable bovine isolate

\section{Phenotypic and serological changes in the dormant cells}

No detectable changes in cell morphology and size were observed using light microscopy for the dormant cells of Streptococcus parauberis when compared with the culturable cells. Both appeared as ovoid cocci about $1 \mu \mathrm{m}$ in diameter. Serological assays demonstrated that dormant cells of $S$. parauberis were antigenically similar to the culturable cells, since a strong agglutination was observed for each strain with its homologous antiserum. In addition, similar agglutination titers of 1024 (expressed as the reciprocal of the highest dilution of antiserum that yielded a positive reaction) were obtained in the microagglutination assays for the original and dormant strains.

\section{DISCUSSION}

Streptococcus parauberis, classically known as an etiological agent of mastitis in cattle, was responsible for important disease outbreaks in turbot cultured in the north of Spain between 1993 and 1996 (Toranzo et al. 1994, 1995, Domenech et al. 1996, Romalde et al. 1996). Vaccination allowed for control of this disease (Romalde et al. 1999a), although fish streptococcosis continues to be endemic in some turbot farms, which constitutes a potential danger for new outbreaks of the disease (Romalde et al. 1999b). In addition, since the main transmission route of the pathogen is horizontal (Romalde et al. 1996), through the water or by direct contact with infected fish, it is important to determine the possible role of the marine environment as a reservoir of the disease.

In this study we have found that the Streptococcus parauberis strains are able to survive in a culturable state for $1 \mathrm{mo}$ in seawater and 6 mo in marine sediment under experimental conditions. On the other hand, when bacterial numbers were below the detection limit by the plate count method, the AO and DAPI counts remained at very high levels $\left(10^{5}\right.$ cells $\mathrm{ml}^{-1}$, average value) and metabolic activity persisted at a lower rate. Although it has been reported that $\mathrm{AO}$ staining may not differentiate between highly active and dead cells (both stained orange) (Colwell \& Grimes 2000), the possibility of finding highly active cells in the water and sediment microcosms is almost null, so this problem can be ignored. In addition, the DAPI procedure, which stains only live cells, rendered the same results as the AO method. Therefore, the analysis of the results obtained by the different methods indicates that $S$. parauberis enters into a dormant or somnicell phase under starvation conditions in seawater. Similar findings were reported for other fish pathogens such as Vibrio anguillarum, V. salmonicida (Hoff 1989) and Yersinia ruckeri (Romalde et al. 1994), but in contrast to $S$. parauberis, all of them are Gramnegative bacteria. To our knowledge few studies of the VBNC state have been reported for Gram-positive microorganisms, although Enterococcus faecalis was recently shown to enter into the VBNC state in the aquatic environment (Lleó et al. 1998, 2000).

On the other hand, the VBNC cells of the 2 Streptococcus parauberis strains showed the capacity to respond rapidly to nutrient addition by returning to a culturable state, which indicated that although the cells may exist in a dormant state, they are capable of resuming active growth (resuscitation) when nutrient conditions are favorable. Twenty four hours after the addition of fresh medium to the microcosms, we observed that the culturable counts reached those of the initial inocula.

It has been reported that cell phenotypical and physiological adjustments are needed for survival when bacteria become exposed to starvation conditions in the aquatic environment (Östling et al. 1993). These adjustments are more evident when bacteria enter a VBNC state. Among the reported cell changes occurring during the dormant phase are a decrease in size, morphology transformation (from rod-shaped to coccoid forms), degradation of endogenous material, quantitative and qualitative changes in protein and 
fatty acid content, cell wall modifications and variation in the RAPD profiles (Linder \& Oliver 1989, Nyström et al. 1990, 1992, Östling et al. 1993, Warner \& Oliver 1998, Lleó et al. 2000). The reverse changes, including synthesis of proteins characteristic of the culturable state and recovery of typical morphology, take place in the process of resumption of growth. In our study, no size or morphology changes were observed by light microscopy during the nonculturable phase. In the analysis of the effect of inhibitors on the cell reactivation from the VBNC state, a complete inhibition was observed when chloramphenicol was added to reactivated bacteria. However, no effect of ampicillin was detected. These results indicate that active protein but not peptidoglycan synthesis occurs during resuscitation, which match with the absence of size or morphology changes observed by light microscopy during the nonculturable phase. Moreover, these findings strongly support the resuscitation hypothesis instead of the overgrowth of rare culturable cells, since the latter would require the synthesis of new cell walls and therefore peptidoglycan.

The maintenance of virulence during the VBNC state is a matter of controversy. It has been demonstrated that a number of bacterial pathogens retain virulence capacities during dormancy (Magariños et al. 1994, Romalde et al. 1994, Huq et al. 2000). Reports are less frequent describing pathogenic bacteria that lose their infectivity when they enter in the VBNC state (Rose et al. 1990, Forsman et al. 2000). The virulence assays performed in the present work demonstrated that the loss of culturability of the turbot isolate of Streptococcus parauberis does not imply the disappearance of its infective potential, since nonculturable cells were able to kill turbot fingerlings. Therefore, even in the VBNC state, $S$. parauberis poses a fish farming threat. In addition, although no mortalities were observed in fish inoculated with the cattle isolate, we cannot rule out its virulence for fish under stressful conditions or even the possibility of strain adaptation to a different host after multiple contacts or by slight phenotypic or genetic changes.

In conclusion, the persistence of the fish pathogen Streptococcus parauberis in seawater and sediment, together with the maintenance of virulence in the dormant state, indicates that the marine environment plays an important role as a reservoir of this fish pathogen. On the one hand, maintenance of the culturable state for long periods in sediments could easily explain the endemic nature of the disease observed in some turbot farms. On the other hand, the existence of virulent nonculturable forms in water could be the cause of many fish streptococcosis outbreaks for which a determined origin of infection could not be demonstrated. Further studies are being performed in order to better understand the survival strategies of $S$. parauberis, which will be helpful to the development of suitable detection methods for VBNC forms of this fish pathogen. Such methods could become an appropriate tool to assess sanitary conditions of turbot culturing facilities and, therefore, to prevent disease outbreaks.

Acknowledgements. This work was supported in part by Grants MAR99-0478 from the Comisión Interministerial de Ciencia y Tecnología (CICYT), Ministerio de Educación y Cultura (Spain), and FEDER 1FD97-0156 from the European Union and the Comisión Interministerial de Ciencia y Tecnología (CICYT), Ministerio de Educación y Cultura (Spain).

\section{LITERATURE CITED}

Austin B, Austin DB (1993) Bacterial fish pathogens. Disease in farmed and wild fish, 2nd edn. Ellis Horwood, Chichester

Colwell RR (2000) Bacterial death revisited. In: Colwell RR, Grimes DJ (eds) Nonculturable microorganisms in the environment. ASM Press, Washington, DC, p 325-342

Colwell RR, Grimes DJ (2000) Semantics and strategies In: Colwell RR, Grimes DJ (eds) Nonculturable microorganisms in the environment. ASM Press, Washington, DC, p 1-6

Domenech A, Fernández-Garayzabal JF, Pascual C, García JA, Cutuli MT, Moreno MA, Collins MD, Domínguez L (1996) Streptococcosis in cultured turbot, Scophthalmus maximus (L.), associated with Streptococcus parauberis. J Fish Dis 19:33-38

Forsman M, Henningson EW, Larsson E, Johansson T, Sandström G (2000) Franciscella tularensis does not manifest virulence in viable but non-culturable state. FEMS Microbiol Ecol 31:217-224

Hoff KA (1989) Survival of Vibrio anguillarum and Vibrio salmonicida at different salinities. Appl Environ Microbiol 55:1775-1786

Huq A, Rivera ING, Colwell RR (2000) Epidemiological significance of viable but nonculturable microorganisms. In: Colwell RR, Grimes DJ (eds) Nonculturable microorganisms in the environment. ASM Press, Washington, DC, p 301-323

Kusuda R, Salati F (1993) Major bacterial diseases affecting mariculture in Japan. Annu Rev Fish Dis 3:69-85

Linder K, Oliver JD (1989) Membrane fatty acid and virulence changes in the viable but nonculturable state in Vibrio vulnificus. Appl Environ Microbiol 55:2837-2842

Lleó MM, Tafi MC, Canepari P (1998) Nonculturable Enterococcus faecalis cells are metabolically active and capable of resuming active growth. Syst Appl Microbiol 21: 333-339

Lleó MM, Pierobon S, Tafi MC, Signoretto C, Canepari P (2000) mRNA detection by reverse transcription-PCR for monitoring viability over time in an Enterococcus faecalis viable but non culturable population maintained in a laboratory microcosm. Appl Environ Microbiol 66:4564-4567

Magariños B, Romalde JL, Barja JL, Toranzo AE (1994) Evidence of a dormant but infective state of the fish pathogen Pasteurella piscicida in seawater and sediment. Appl Environ Microbiol 60:80-186 
Magariños B, Romalde JL, Cid A, Toranzo AE (1997) Viability of starved Pasteurella piscicida in seawater monitored by flow cytometry and the effects of antibiotics on its resuscitation. Lett Appl Microbiol 24:1-5

Morgan JAW, Winstanley C (1996) Survival of bacteria in the environment. In: Pickup RW, Saunders JR (eds) Molecular approaches to environmental, microbiology. Ellis Horwood, Cambridge, p 226-241

Nyström T, Albertson NH, Flärdh K, Kjelleberg S (1990) Physiological and molecular adaptation to starvation and recovery from starvation by the marine Vibrio sp. S14. FEMS Microbiol Ecol 74:129-140

Nyström T, Olson RM, Kjelleberg S (1992) Survival, stress resistance, and alterations in protein expression in the marine Vibrio sp. strain S14 during starvation for different individual nutrients. Appl Environ Microbiol 58:55-65

Oliver JD, Nilsson L, Kjelleberg S (1991) Formation of nonculturable Vibrio vulnificus cells and its relation in the starvation state. Appl Environ Microbiol 57:2640-2644

Oliver JD, Hite F, McDougald D, Aldon NL, Simpson LM (1995) Entry into, and resuscitation from, the viable but nonculturable state by Vibrio vulnificus in an estuarine enviroment. Appl Environ Microbiol 61:2624-2630

Östling J, Holmquist L, Flärdh K, Svenblad B, Jouper-Jaan Å, Kjelleberg S (1993) Starvation and recovery of Vibrio. In: Kjelleberg S (ed) Starvation in bacteria. Plenum Press, New York, p 103-127

Porter KG, Fieg YS (1980) The use of DAPI for identifying and counting aquatic microflora. Limnol Oceanogr 25:943-948

Romalde JL, Barja JL, Magariños B, Toranzo AE (1994) Starvation-survival processes of the bacterial fish pathogen Yersinia ruckeri. Syst Appl Microbiol 17:161-168

Romalde JL, Magariños B, Nuñez S, Barja JL, Toranzo AE

Editorial responsibility: David Bruno, Aberdeen, Scotland, UK
(1996) Host range susceptibility of Enterococcus sp. strains isolated from diseased turbot: possible routes of infection. Appl Environ Microbiol 62:607-611

Romalde JL, Magariños B, Villar C, Barja JL, Toranzo AE (1999a) Genetic analysis of turbot pathogenic Streptococcus parauberis strains by ribotyping and random amplified polymorphic DNA. FEMS Microbiol Lett 179:297-304

Romalde JL, Magariños B, Toranzo AE (1999b) Prevention of streptococcosis in turbot by intraperitoneal vaccination: a review. J Appl Ichthyol 15:153-158

Rose AS, Ellis AE, Munro ALS (1990) Evidence against dormancy in the bacterial fish pathogen Aeromonas salmonicida. FEMS Microbiol Lett 68:103-107

Roszak DB, Colwell RR (1987) Survival strategies of bacteria in the natural enviroment. Microbiol Rev 51:365-379

Toranzo AE, Devesa S, Heinen P, Riaza A, Nuñez S, Barja JL (1994) Streptococcosis in cultured turbot caused by an Enterococcus-like bacterium. Bull Eur Assoc Fish Pathol 14:19-23

Toranzo AE, Cutrín JM, Nuñez S, Romalde JL, Barja JL (1995) Antigenic characterization of Enterococcus strains pathogenic for turbot and their relationship with other Gram positive bacteria. Dis Aquat Org 21:187-191

Warner JM, Oliver JD (1998) Randomly amplified polymorphic DNA analysis of starved and viable but nonculturable Vibrio vulnificus cells. Appl Environ Microbiol 64: 3025-3028

Williams SC, Hong Y, Danavall DCA, Howard-Jones MH, Gibson D, Frischer ME, Verity PG (1998) Distinguishing between living and nonliving bacteria: evaluation of the vital stain propidium iodide and its combined use with molecular probes in aquatic samples. J Microbiol Methods $32: 225-236$

Submitted: February 25, 2002; Accepted: June 24, 2002 Proofs received from author(s): November 7, 2002 